https://www.rush.ru/upload/main/vestnik/eup_1_2020. pdf (д'ата обра'щения 30.06.2020).

3. Коз'лова Д. Цифр'овая доб'ыча неф'ти: тюн'инг для отра'сли/ Д. Козл'ова, Д. Пига'рев. VYGONCon'sulting, ию'нь 20‘18. - 60 с. Шаг в буду'щее: искусс'твенный инте'ллект и цифр'овая экон'омика - $316 \mathrm{c}$.

4. Митатал А. От бай'тов к барр'елям: Цифр'овая трансф'ормация в сф’ере разв'едки и доб'ычи не'фти и га‘3а/ А. Мит'тал, Э. Сло‘тер, В. Бан'сал. - Delo'itte Insi'ghts: Отчет Цен'тра реш'ений «Дел'ойта» для предп'риятий энергет'ического

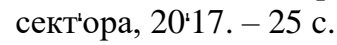

5. Ник'итин Б.'А., Дзю'бло А.'Д., Хал'имов К.Э., Стор'ожева А.'Е. Ресу'рсная ба'за и персп'ективы осво'ения газоконд'енсатных местор'ождений Кирин'ского бл'ока // Дел'овой жур'нал Nefteg'az.RU. - 201'3.- № 6. - c. 12-'16.

6. Стор'ожева А.'Е. Совершен'ствование гидродинамической мод'ели Кирин'ского местор'ождения для повы'шения эффект'ивности разра'ботки в усло'виях геолог'ической неопреде`ленности: ди'c. ка'нд. теххн. на'ук: 25.0`0.18. - РГУ не'фти и га'за (Н'ИУ) им'ени И.'М. Губк'ина, 20¹8 - 129 с.

7. Цифр'овая трансф’ормация нефтегазовой отра'сли: попул'ярный миф или объек'тивная реальн'ость// Ежеме'сячное информ'ационно аналит'ическое изд'ание «Нефт'егаз». - 20‘17. - №2.

8. Шаг в буду'щее: искусс'твенный инте'ллект и цифр'овая эконо'мика. Рево'люция в управ'лении: но'вая цифр'овая экон'омика или но'вый мир маш'ин: мате'риалы II Междуна'родного науч'ного фор'ума. Вып. 1 / Государ'ственный униве'рситет управ'ления. - М.: Издате'льский дом ГУУ,201'8.$390 \mathrm{c}$.

9. BP Techn'ology Out'look 20'18: How techn'ology co'uld cha'nge the way ene'rgy is prod'uced and cons'umed. - UK, L., 20'18.

10. The intel'ligent refi'nery // Accen'ture, Ju'ne 5, $200^{4} 18$ [Elec'tronic resou'rce]. - Mo'de of acc'ess: https://www.accenture.com/us-en/insights/industry-x0/2018-digital-refining-survey ( да'та обра'щения : 05.07.2020).

UDC: 364,311

\title{
MAIN AREAS OF SOCIAL SECTOR AND DEMOGRAPHIC DEVELOPMENT IN NAKHCHIVAN
} AUTONOMOUS REPUBLIC

\author{
Ibrahimov E.Y \\ Doctor of Philosophy in Economic Sciences \\ Director of "Economy” Department Of Nakhchivan Divison of ANAS \\ AZ7000, Nakhchivan city, Haydar Aliyev prospect, 76 \\ Nagiyev K.Z \\ Doctor of Philosophy in Economic Sciences \\ Researcher of " Economy” Department Of Nakhchivan Divison of ANAS \\ AZ7000, Nakhchivan city, Haydar Aliyev prospect, 76 \\ DOI: 10.31618/ESU.2413-9335.2020.4.76.916
}

\section{SUMMARY}

Creating important products and services which fit the material and spiritual needs of people, forming all civil and proper activities of people applicatively and being the main sources of their general needs, social spheres are the key factors of economical growth. As social spheres are intensely related to human factors, the sustainability of human development is a key condition in this context. The multiple challenges in human life, the protection of the minimum life standards, meet the increasing demands via affordable ways and other related issues require to form a proper social system. The article concerns about the social spheres, their present situation and demographic changes in Nakhchivan Autonomous Republic living blockade.

Keywords: social spheres, autonomous republic, social development strategy, demographic development, population

\section{Introduction}

Nowadays, many strategies and concepts have been specified, state programs have been adopted to ensure economic and social development and implement vital state projects in Azerbaijan. In fact, these strategies and concepts, decrees and orders are the main methods of legal regulation in the effective implementation of ongoing programs.

In terms of economic and social development structures, by looking at the main features of the regions of our country, it should be noted that Nakhchivan Autonomous Republic is very important in this regard. Because the Nakhchivan Autonomous Republic is considered one of the most important economic regions of our country, both economically and geographically. It should also be noted that the processes taking place in the autonomous republic differ from other economic regions in that it has been under blockade for many years as a result of the Armenian aggression and lives in difficult economic and social conditions. However, in the face of all the existing complex conditions and difficult processes, the autonomous republic has determined an effective course of socio-economic policy and formed a governance structure.

\section{The main part}

Studies show that Nakhchivan Autonomous Republic, like other regions of Azerbaijan, achieved great success in the economic spheres in the 70 s and 80s. Economic potential was discovered in 
Nakhchivan, regular inclusion of a range of natural resources in the production turnover has laid the foundation for the creation of new industrial enterprises and the integrated development of industry. The new opportunities created favorable conditions for the wider development of productive forces in the autonomous republic, as well as the realized the possibility of attracting its rich natural resources to manufacture turnover [1, s 94].

The main social spheres in the Autonomous Republic are its science and education, health, sports, culture, housing and communal services, social insurance and social protection, as well as trade and tourism industry. The current status of these areas, ongoing processes, emerging problems, are the main criteria that determine the social development dynamics in the autonomous republic. It should be noted that the role of the government in achieving social development and proper regulation is irreplaceable. The state ensures the comprehensive development of the socially oriented economy through the established methods of regulation. "State regulation of social development combines with the state the management of objective mechanisms that meet the needs of the population. Before regulating social development, it is important to know the essence of social objects, to analyze the economic and social processes that reflect their formed regularities and determine their future dynamics [2, s 27]. The timely examination of these processes and the identification of necessary problems are the main objectives of the state's economic and social policy.

On the other hand, country groups are at different stages of demographic transition, in line with the difference in development levels. While today's developed countries have completed their demographic transition, it is possible to say that developing countries have advanced significantly. The least developed countries have just started the demographic transition. In this case, developing countries and least developed countries will continue to see significant changes in population structures in the coming period [8].

It should be noted that Nakhchivan has a wide legal framework and government support for the development of social spheres. All measures and state programs related to regional socio-economic development in our country have also been adopted in the autonomous republic and works are being carried out in accordance with these programs continuously.

First of all, let's look at the structure of some of the programs adopted by the orders of the Chairman of the Supreme Assembly of the Autonomous Republic in various fields:

1. Regional Development Program of Nakhchivan Autonomous Republic (2005-2008)

2. State Program on socio-economic development of Nakhchivan Autonomous Republic for 2009-2013 years

3. State Program on socio-economic development of Nakhchivan Autonomous Republic for 2014-2018 years

4. Order of the Chairman of the Supreme Assembly (Ali Majlis) of Nakhchivan Autonomous
Republic on "Additional measures related to the organization of e-learning in educational institutions of Nakhchivan Autonomous Republic.

5. State Program on Education and Rehabilitation of Children with Impaired Health in Nakhchivan Autonomous Republic in 2016-2020 years

6. State Program on increasing employment in the Nakhchivan Autonomous Republic in 2016-2020

7. Action Plan on formation of electronic payment area and increase of non-cash settlements in Nakhchivan Autonomous Republic (2013-2015)

8. State Program on Strengthening Social Protection of Elderly People in Nakhchivan Autonomous Republic

9. On the prevention of interference that hinders the development of entrepreneurship, etc.

These programs have created significant opportunities to increase the efficiency of the socioeconomic environment in the autonomous republic, to solve problems in certain areas.

There is a wide range of material and technical base for education formed in Nakhchivan AR. Both primary and higher education are well-established, and the protection of identified interests in education is carried out by important vocational and educational institutions. The education system in Nakhchivan consists of universities, vocational schools and secondary schools. Universities and special vocational schools can be found in Nakhchivan, and secondary schools can be found both in Nakhchivan and other regions.

Nakhchivan State University, Nakhchivan Teachers' Institute and Nakhchivan University are the main universities of the autonomous republic. Hundreds of students from the autonomous republic, other cities and regions, as well as foreign countries study at these universities. The educational base of the universities is located in newly renovated buildings at a high level and organized in accordance with international standards. Staff graduated from foreign and local universities teach here, many doctors of sciences, professors, candidates of sciences and associate professors are among them.

Universities have rich libraries, the latest modern technological equipments, large auditoriums and gyms. Universities have also established various levels of relations with other universities in neighboring and European countries.

The main special colleges of the autonomous republic are Nakhchivan Medical College, Nakhchivan Music College, Nakhchivan State Technical College and the Military Lyceum named after Heydar Aliyev, which play very important role in the training of personnel in relevant fields.

In addition to these indicators in education, many works have been carried out to attract people who are with poor access to education in recent years. Thus, as a result of the implementation of "State Program on Involvement Children with Impaired Health in Education in Nakhchivan Autonomous Republic", the involvement of people with physical and mental disabilities, in education has become systemic and comprehensive opportunities have been created for 
them. At the same time, Distance Education Center has been established to provide education for children with disabilities who are unable to attend classes. All the necessary issues mentioned in the state program for 2016-2020 in a similar area will be kept in the center of attention.

Health care is one of the most important and considered areas of the social sphere in the Autonomous Republic. Compared to previous years, it can be said that important measures have been taken in the health system in recent years and the health infrastructure has been updated. At present, there are no traces of old medical centers here. There are a lot of hospitals, dispensaries and outpatient hospitals both in the city of Nakhchivan and in the regions. In addition, there are also natural treatment facilities here. The most important of them are Daridag Balneological Center, Duzdag Physiotherapy Center and Badamli Physiotherapy Hospital, which annually receive a large number of people from other regions and cities of the country, as well as from abroad for treatment.
Studies show that the Nakhchivan Autonomous Republic, which is an integral part of the Republic of Azerbaijan, has its own characteristics of demographic development. According to the first national census conducted in the independent Republic of Azerbaijan on January 27, 1999, the number of people living here was 354.1 thousand. 95.1 thousand people or $26.9 \%$ of them settled in urban areas, while 259.0 thousand people or $73.1 \%$ in rural areas. During that period, 174.5 thousand people or $49.3 \%$ of the population of the autonomous republic were men, 179.6 thousand people or $50.7 \%$ were women. According to statistics as of January 1, 2020, the population of the Nakhchivan Autonomous Republic was 459.6 thousand people. According to statistics as of January 01, 2020, the population of Nakhchivan Autonomous Republic was 459.6 thousand people. 135.6 thousand people or $29.5 \%$ of them live in urban areas, 324.0 thousand people or $70.5 \%$ live in rural areas. 229.6 thousand people or $50.0 \%$ of the population are men, 230.0 thousand people or $50.0 \%$ are women.

Table 1

\section{Population and gender distribution in the Nakhchivan Autonomous Republic} (thousand at the beginning of the year)

\begin{tabular}{|c|c|c|c|c|c|c|c|c|c|}
\hline \multirow{2}{*}{ Years } & \multirow{2}{*}{$\begin{array}{l}\text { Number } \\
\text { of } \\
\text { population } \\
\text { (in } \\
\text { thoush.) }\end{array}$} & \multicolumn{2}{|c|}{ including } & \multicolumn{2}{|c|}{$\begin{array}{l}\text { for the entire } \\
\text { population, } \%\end{array}$} & \multicolumn{2}{|c|}{ including } & \multicolumn{2}{|c|}{$\begin{array}{l}\text { for the entire } \\
\text { population, } \%\end{array}$} \\
\hline & & urban & rural & urban & rural & males & females & males & females \\
\hline 1999 & 354,1 & 95,1 & 259,0 & 26,9 & 73,1 & 174,5 & 179,6 & 49,3 & 50,7 \\
\hline 2000 & 358,8 & 96,2 & 262,6 & 26,8 & 73,2 & 177,0 & 181,8 & 49,3 & 50,7 \\
\hline 2001 & 363,1 & 97,1 & 266,0 & 26,7 & 73,3 & 179,2 & 183,9 & 49,4 & 50,6 \\
\hline 2002 & 366,9 & 97,8 & 269,1 & 26,7 & 73,3 & 181,1 & 185,8 & 49,4 & 50,6 \\
\hline 2003 & 370,4 & 98,9 & 271,5 & 26,7 & 73,3 & 181,6 & 188,8 & 49,0 & 51,0 \\
\hline 2004 & 373,9 & 110,1 & 263,8 & 29,4 & 70,6 & 186,0 & 187,9 & 49,7 & 50,3 \\
\hline 2005 & 377,8 & 110,9 & 266,9 & 29,4 & 70,6 & 187,3 & 190,5 & 49,6 & 50,4 \\
\hline 2006 & 382,1 & 111,6 & 270,5 & 29,2 & 70,8 & 189,7 & 192,4 & 49,6 & 50,4 \\
\hline 2007 & 386,0 & 112,3 & 273,7 & 29,1 & 70,9 & 191,7 & 194,3 & 49,7 & 50,3 \\
\hline 2008 & 391,8 & 114,2 & 277,6 & 29,1 & 70,9 & 193,0 & 198,8 & 49,3 & 50,7 \\
\hline 2009 & 397,3 & 115,4 & 281,9 & 29,0 & 71,0 & 197,8 & 199,5 & 49,8 & 50,2 \\
\hline 2010 & 402,4 & 116,7 & 285,7 & 29,0 & 71,0 & 200,0 & 202,4 & 49,7 & 50,3 \\
\hline 2011 & 410,1 & 119,5 & 290,6 & 29,1 & 70,9 & 204,2 & 205,9 & 49,8 & 50,2 \\
\hline 2012 & 418,5 & 121,7 & 296,8 & 29,1 & 70,9 & 208,2 & 210,3 & 49,7 & 50,3 \\
\hline 2013 & 427,2 & 123,9 & 303,3 & 29,0 & 71,0 & 212,5 & 214,7 & 49,7 & 50,3 \\
\hline 2014 & 435,3 & 127,2 & 308,1 & 29,2 & 70,8 & 216,7 & 218,6 & 49,8 & 50,2 \\
\hline 2015 & 439,8 & 128,2 & 311,6 & 29,1 & 70,9 & 219,1 & 220,7 & 49,8 & 50,2 \\
\hline 2016 & 444,4 & 131,0 & 313,4 & 29,5 & 70,5 & 221,6 & 222,8 & 49,9 & 50,1 \\
\hline 2017 & 449,1 & 132,4 & 316,7 & 29,5 & 70,5 & 224,1 & 225,0 & 49,9 & 50,1 \\
\hline 2018 & 452,8 & 133,6 & 319,2 & 29,5 & 70,5 & 226,0 & 226,8 & 49,9 & 50,1 \\
\hline 2019 & 456,1 & 134,5 & 321,6 & 29,5 & 70,5 & 227,7 & 228,4 & 49,9 & 50,1 \\
\hline 2020 & 459,6 & 135,6 & 324,0 & 29,5 & 70,5 & 229,6 & 230,0 & 50,0 & 50,0 \\
\hline
\end{tabular}

Note: Materials of the Statistical Committee of Nakhchivan AR

As can be seen from the table above, the number and structure of the population in the Nakhchivan Autonomous Republic did not remain stable and changed in different forms and directions at different stages of historical development as a result of demographic, socio-economic, national-cultural and other factors. Sustainable development covering all sectors of the economy in the Autonomous Republic, as well as comprehensive development of social spheres and health care system, creation of new jobs, increase of employment, poverty reduction and successful implementation of other socio-economic measures have resulted in positive changes in the dynamics of population. Thus, in 1999-2020, the population of the Nakhchivan Autonomous Republic increased by 105.5 thousand people or $29.8 \%$ from 354.1 thousand to 459.6 thousand people, including the urban population of 40.5 thousand people or $42.6 \%$ increase from 95.1 
thousand to 135.6 thousand people, and the rural population increased by 65 thousand people or $25.1 \%$ from 259.0 thousand to 324.0 thousand people, as well as the number of men 55.1 thousand people and or $31.6 \%$ from 174.5 thousand to 229.6 thousand, and the number of women increased by 50.4 thousand or $28.1 \%$ from 179.6 thousand to 230.0 thousand.

The increase in population in each region means the expansion of employment opportunities in that area. The level of employment of the population, first of all, shows the level of participation of all or part of the ablebodied population in social production, and secondly, the level of participation of the population belonging to different classes and social groups in public activity. The involvement of the population in any activity that does not violate the laws of the country is related to meeting their personal and public needs and, as a rule,it is profitable, livelihood and an important condition of social welfare [6, p 27].

"State Program on Increasing Employment in the Nakhchivan Autonomous Republic in 2016-2020" plans to create favorable conditions for ensuring effective employment in the years envisaged as a continuation of the social policy of previous years. The program is aimed at creating favorable opportunities for job seekers, ensuring the adequacy of the workforce and the labor market, assessing the current state of supply and demand in the market, etc. Looking at the indicators of previous years, we can show that as a result of measures taken to increase employment in 2014-2015, "6364 new job places were created, analysis was conducted to determine supply and demand in the labor market, 5537 job seekers were provided with job vacancies, 627 people were sent to public works, 7595 people were involved in vocational courses organized for job seekers in accordance with the requirements of the labor market. Employment of socially vulnerable groups was also taken into account, 158 people were sent to quota places, 171 people with disabilities were sent to suitable jobs, 161 people with disabilities were involved in vocational courses. A number of social projects have been implemented to ensure women's self-employment "[4].

Implementation of social policy in the Autonomous Republic at the level of modern requirements is ultimately a key criterion in the efficient use of funds, increasing business activity, improving the comprehensive provision of various groups, ensuring economic recovery and strengthening demographic potential.

\section{Conclusion}

- Social policy and demographic development are closely linked. Strengthening social protection has a positive effect on population growth over the years.

- The fact that people are engaged in any labor activity that does not contradict the law is a key factor in improving their well-being.

- Many programs in the social sphere have been adopted in Nakhchivan, which indicates that these areas are under state control.

- The steady growth of the population over the years is seen in parallel with the implementation of social programs

\section{BIBLIOGRAPHY}

1.Ahmadov. N.H. The economy of the Nakhchivan Autonomous Republic in 90 years. Nakhchivan: Ajami, 2015, 272 p

2.Alirzayev A.Q. Economics and management of the social sphere. Baku: University of Economics, 2010, $326 \mathrm{p}$

3.Hajizade E.M. Socializing Economy. Baku: Elm, 2006, $509 \mathrm{p}$

4.http://www.serqqapisi.az. Official website of "Sharq Qapisi" newspaper

5.http://www.statistika.nmr.az Official website of the State Statistics Committee of Nakhchivan AR

6.Muradov. R.Ş. Problems of formation and improvement of the employment structure of the population at the present stage. Baku: Elm, 2006, 216 p

7.Muradov. Ş.M. Human potential, main trends, realities, problems. Baku: Elm, 2004, 600 p

8.Demographic Developments

Macroeconomic

and https://www.tcmb.gov tr/wps/wcm/connect/3ct20335$27 \mathrm{ca}-4 \mathrm{~b} 38-97 \mathrm{~d} 2-$

ebdd91e899ba/wp1911.pdf?MOD=AJPERES\&CACHE ID=ROOTWORKSPACE-3cf20335-27ca-4b38-97d2ebdd91e899ba-mGcScM7

\title{
ГОСУДАРСТВО И ОБЩЕСТВО В ЦИФРОВОЙ ТРАНСФОРМАЦИИ ЭКОНОМИКИ
}

\author{
Кононкова Н.П. \\ д.э.н., доцент экономического факультета \\ МГУ имени М.В. Ломоносова \\ Россия, Москва, Ленинские горы, д.1 \\ DOI: 10.31618/ESU.2413-9335.2020.4.76.923
}

\footnotetext{
АННОТАЦИЯ

Данная статья посвящена анализу цифровой трансформации экономических отношений, возможностей и рисков для экономических агентов, политики правительства, направленной на адаптацию бизнеса и общества к новым условиям экономического развития с учетом пандемических шоков. Автор приходит к выводу о том, что в условиях современных вызовов экономическому развитию, обусловленных цифровой трансформацией экономических отношений и пандемией COVID-19, парализовавшей экономику во многих странах мира, успешный выход национальных экономик из шокового состояния во многом определяется усилиями и адекватной политикой государства, а также скоростью принятия решений.
} 